\title{
GAMBARAN PERSEPSI DAN KEBIASAAN PADA MASA KEHAMILAN DI DUSUN GUNUNG KAWUNG KECAMATAN SINGAPARNA TAHUN 2017
}

\author{
Chanty Yunie Hartiningrum, SST., M.Kes \\ chanty.yunie@gmail.com \\ Milan
}

\section{A. ABSTRAK}

Target Angka Kematian Ibu (AKI) di Indonesia pada tahun 2015 adalah 102 kematian per 100.000 kelahiran hidup. Sementara itu berdasarkan Survei Demografi dan Kesehatan Indonesia (SDKI) tahun 2012, Angka Kematian Ibu (AKI) (yang berkaitan dengan kehamilan, persalinan, dan nifas) sebesar 359 per 100.000 kelahiran hidup. Salah satu cara untuk menurunkan AKI di Indonesia adalah dengan persalinan ditolong oleh tenaga kesehatan yang terlatih dan melakukan persalinan di fasilitas pelayanan kesehatan. Tujuan penelitian ini untuk mengetahui gambaran persepsi pada masa kehamilan di Dusun Gunung Kawung Kecamatan Singaparna Tahun 2017 dan untuk mengetahui gambaran kebiasaan pada masa kehamilan di Dusun Gunung Kawung Kecamatan Singaparna Tahun 2017.

Penelitian ini adalah penelitian observasional kuantitatif dengan rancangan penelitian deskriptif. Penelitian ini menggambarkan Gambaran Persepsi dan Kebiasaan Pada Masa Kehamilan di Dusun Gunung Kawung Kecamatan Singaparna Tahun 2017. Populasi dalam penelitian ini adalah semua ibu hamil di Gunung Kawung Kecamatan Singaparna Tahun 2017. Sampel penelitian ini adalah ibu hamil di RW 07 dengan teknik pengambilan sampling secara simple random sampling berjumlah $50 \mathrm{ibu}$ hamil.

Kesimpulan penelitian ini antara lain (1) Gambaran karakteristik responden berdasarkan pekerjaan proporsi paling tinggi adalah IRT sebesar 62,0\%, berdasarkan umur yang proporsi terbanyak adalah umur 21-25 sebesar 48,0\%. (2) Gambaran persepsi positif sebesar 90\%, Persepsi pemeriksaan kehamilan ke tenaga kesehatan memiliki memiliki proporsi tinggi $(90,0 \%)$ sedangkan responden yang tidak melakukan pemeriksaan kehamilan ke tenaga kesehatan (10,0\%) (3) Gambaran Kebiasaan ibu hamil mengkonsumsi gizi seimbang setiap hari $(92,0 \%)$. Responden yang tidak memiliki kebiasaan ibu hamil olah raga memiliki proporsi tertinggi $(96,0 \%)$. Saran dalam penelitian ini antara lain (1) sebaiknya usia ketika hamil lebih diperhatikan demi keselamatan dan kesehatan ibu maupun janin yang dikandung, (2) Ibu hamil sebaiknya memiliki persepsi yang baik dalam memeriksakan kehamilan dan selalu berpersepsi yang positif yang sesuai dengan norma agama dan kesehatan (3) Ibu hamil sebaiknya lebih banyak melakukan aktivitas fisik untuk seperti senam hamil dan aktivitas fisik lainnya yang ringan dan mudah dilakukan pada masa hamil.

Kata Kunci : Persepsi, Kebiasaan, Kehamilan 


\section{B. LATAR BELAKANG}

Kehamilan merupakan proses alami dan normal dalam kehidupan wanita pada masa reproduksi. Selama 3 bulan pertama atau pada trimester 1 kehamilan, wanita hamil mengalami perubahan-perubahan fisik maupun psikis untuk mempersiapkan pertumbuhan janin, masa persalinan dan juga menyusui. Keadaan perubahan yang terjadi dapat menimbulkan gangguan dan hambatan dalam kehamilan (Alonto, 2007). Target Angka Kematian Ibu (AKI) di Indonesia pada tahun 2015 adalah 102 kematian per 100.000 kelahiran hidup. Sementara itu berdasarkan Survei Demografi dan Kesehatan Indonesia (SDKI) tahun 2012, Angka Kematian Ibu (AKI) (yang berkaitan dengan kehamilan, persalinan, dan nifas) sebesar 359 per 100.000 kelahiran hidup. Salah satu cara untuk menurunkan AKI di Indonesia adalah dengan persalinan ditolong oleh tenaga kesehatan yang terlatih dan melakukan persalinan di fasilitas pelayanan kesehatan.

Berdasarkan data Profil Kesehatan Indonesia tahun 2013 cakupan pertolongan persalinan oleh tenaga kesehatan secara nasional pada tahun 2013 adalah sebesar 90,88\%. Cakupan ini terus menerus meningkat dari tahun ke tahun (Kemenkes RI, 2014). Visi Indonesia Sehat 2015, merupakan gagasan tentang Safe Motherhood dan Making Safer menjelaskan sebuah gambaran langsung tentang penekanan betapa pentingnya kesehatan ibu hamil dan bersalin. Secara makro dan komprehensif, gagasan ini sangat penting dan strategis untuk menjamin lahir dan tumbuhnya generasi Indonesia yang sehat, dan produktif. Banyak hal yang menyebabkan masih tingginya Angka Kematian Ibu di Indonesia mulai dari budaya sampai dengan permasalahan akses pelayanan kesehatan. Sebesar 90\% kematian ibu disebabkan karena sebab yang secara langsung berkaitan dengan kondisi kehamilan, persalinan dan nifas, seperti perdarahan, eklamsia, partus lama maupun infeksi. Salah satu faktor tingginya AKI di Indonesia adalah karena relatif masih rendahnya cakupan pertolongan oleh tenaga kesehatan. Rendahnya pendidikan di masyarakat, budaya dan ekonomi menjadikan sebagian masyarakat memilih bersalin pada tenaga non kesehatan (dukun). Hasil riset kesehatan dasar (Riskesdas) juga menunjukkan bahwa persalinan oleh tenaga kesehatan di fasilitas kesehatan baru mencapai $55,4 \%$. hal ini menunjukkan bahwa sekitar $43,2 \%$ persalinan masih ditolong oleh dukun (Riskesdas, 2010). Tingginya kematian bayi baru lahir cenderung terjadi pada masa sekitar persalinan, disebabkan antara lain pertolongan tidak dilakukan oleh tenaga kesehatan yang mempunyai kompetensi kebidanan (profesional).

Hasil Riset Kesehatan Dasar (Riskesdas) tahun 2013 menunjukkan bahwa persentase penolong persalinan oleh tenaga kesehatan adalah sebesar hanya $86,9 \%$. Dilihat dari fasilitas tempat melahirkan, hanya $77,6 \%$ persalinan dilakukan di fasilitas kesehatan dan Poskesdes/Polindes. Hal ini berarti bahwa $22,4 \%$ ibu bersalin yang masih melahirkan di rumah (Badan Penelitian Pengembangan Kesehatan, 2013). Beberapa program dan kegiatan yang dilakukan dalam rangka penurunan $\mathrm{AKB}$ dari aspek medis, kebijakan dan manajemen pelayanan kesehatan antara lain adalah meningkatkan cakupan dan meningkatkan kualitas pelayanan kesehatan ibu dan bayi melalui kegiatan dengan target antara lain meningkatkan cakupan persalinan oleh tenaga kesehatan terampil, meningkatkan cakupan pelayanan komplikasi obsteri dan neonatal berkualitas (Pranata, Pratiwi and Rahanto, 2011). Upaya dalam rangka penurunan $\mathrm{AKB}$ sudah dilaksanakan tersebut, belum dapat mengatasi seluruh permasalahan/hambatan dalam upaya 
penurunan AKB masih sulit untuk diatasi. Hal ini karena permasalahan/hambatan AKB juga tidak terlepas dari faktor-faktor sosial budaya dan lingkungan dalam masyarakat dimana mereka berada, seperti hubungan sebab akibat antara makanan dan kondisi sehat-sakit, kebiasaan dan ketidaktahuan masyarakat (Willa, Ruben and Madu, 2014).

Persepsi terhadap mitos kehamilan baik masalah kematian maupun kesakitan pada ibu sesungguhnya tidak terlepas dari faktor-faktor sosial budaya dan lingkungan dalam masyarakat dimana mereka berada. Disadari atau tidak, faktor-faktor kepercayaan dan pengetahuan budaya seperti konsepsikonsepsi mengenai berbagai pantangan, hubungan sebab-akibat antara makanan dan kondisi. sehat-sakit, kebiasaan dan ketidaktahuan, seringkali membawa dampak baik positif maupun negatif terhadap kesehatan reproduksi ibu dan kesehatan anak. Hal ini terlihat bahwa setiap daerah mempunyai pola makan tertentu, termasuk pola makan ibu hamil yang disertai dengan kepercayaan akan pantangan, tabu, dan anjuran terhadap beberapa makanan tertentu (Nirwana, a.B, 2011). Seorang wanita yang sedang hamil memiliki kebiasaan yang berbeda beda dalam menjalani selama kehamilan. Kebiasaan merupakan hal yang dilakukan secara terus menerus yang terbentuk dari kepercayaan yang baik sehingga membentuk perilaku atau kebiasaan yang sehat. Beraneka ragam kebiasaan wanita hamil tergantung pada tingkat pengetahuan, pendidikan, dan tingkat kepercayaan selama kehamilan. Tahapan pembentuk kebiasaan yaitu berawal dari memfokuskan perhatian kemudian mengulang-ulang dan praktik, lalu menunaikan pekerjaan tanpa berpikir atau merasa. Rasa tidak nyaman pada ibu hamil yang disebabkan oleh perubahan hormonal yang meliputi ketidaknyamanan pada trimester 1 berupa nyeri payudara, sering kencing, gusi berdarah, mengidam makanan, kelelahan, keputihan, ptyalism, pusing, mual dan muntah, pada trimester 2 berupa sulit $\mathrm{BAB}$, wasir, perut kembung, heartburn, serta ketidaknyamanan pada trimester 3 berupa sulit tidur, nyeri punggung.

Berdasarkan studi pendahuluan pada tanggal 28 Maret 2017 dengan melakukan wawancara kepada 10 kader posyandu menyatakan bahwa ibu hamil di Dusun Gunung Kawung Kecamatan Singaparna menyatakan bahwa persepsi terhadap mitos kehamilan dengan persepsi positif sebanyak $70 \%$, dan $30 \%$ dengan persepsi negatif, sedangkan kebiasaan ibu hamil yaitu $60 \%$ masih memeriksakan ke paraji, dan $40 \%$ ke tenaga kesehatan (Kader Posyandu Gunung Kawung, 2017).

Hal ini menyatakan bahwa sebagian besar masyarakat masih percaya atau memiliki persepsi terhadap mitos masih kental. Sehingga dikhawatirkan persepsi yang tidak sejalan dengan perspektif agama dan kesehatan semakin berkembang yang tidak mendukung terhadap kesehatan ibu dan anak. Berdasarkan uraian di atas peneliti tertarik untuk meneliti "Gambaran Persepsi dan Kebiasaan Pada Masa Kehamilan di Dusun Gunung Kawung Kecamatan Singaparna Tahun 2017"

\section{METODE PENELITIAN}

Penelitian ini adalah penelitian observasional kuantitatif dengan rancangan penelitian deskriptif. Penelitian ini menggambarkan Gambaran Persepsi dan Kebiasaan Pada Masa Kehamilan di Dusun Gunung Kawung Kecamatan Singaparna Tahun 2017.

\section{HASIL PENELITIAN}

1. Analisis Univariat Karakteristik Responden

Berdasarkan hasil penelitian dapat diketahui gambaran karakteristik responden penelitian Di Gunung Kawung sebagai berikut: 
a. Distribusi Responden Berdasarkan Pekerjaan Berdasarkan hasil wawancara yang dilakukan, maka distribusi responden.

Tabel 4.1 Distribusi Karakteristik Responden berdasarkan pekerjaan

\begin{tabular}{cccc}
\hline No & Jenis & \multicolumn{2}{c}{ Responden } \\
\cline { 3 - 4 } & Kelamin & Jumla & Persen \\
& Balita & h & tase \\
1. & IRT & 31 & 62,0 \\
2. & Pedagang & 19 & 38,0 \\
& Jumlah & 50 & 100,0 \\
\hline
\end{tabular}

berdasarkan pekerjaan dapat diketahui pada Tabel 4.1menunjukkan bahwa responden IRT memiliki proporsi paling banyak $(62,0 \%)$ dibandingkan responden pedagang $(38,0 \%)$.

b. Distribusi Responden Berdasarkan umur Berdasarkan hasil wawancara yang dilakukan, maka distribusi responden berdasarkan umur dapat diketahui pada Tabel 4.2

Tabel 4.2 Distribusi Karakteristik Responden Berdasarkan Golongan Umur

\begin{tabular}{|c|c|c|c|}
\hline \multirow[t]{2}{*}{ No } & \multirow[t]{2}{*}{ Umur } & \multicolumn{2}{|c|}{ Responden } \\
\hline & & Jumlah & Persentase \\
\hline 1. & $16-20$ & 9 & 18,0 \\
\hline 2. & $21-25$ & 24 & 48,0 \\
\hline 3. & $26-30$ & 17 & 34,0 \\
\hline & Jumlah & 5( & 100,0 \\
\hline
\end{tabular}

Tabel 4.2 menunjukkan bahwa responden yang berumur 21-25 tahun memiliki proporsi tertinggi $(48,0)$, sedangkan responden yang berumur 16-20 tahun memiliki proporsi terendah $(18,0)$.

\section{Analisis Univariat Variabel Penelitian a. Persepsi ibu hamil}

Berdasarkan hasil wawancara yang dilakukan, distribusi frekuensi persepsi ibu hamil dapat diketahui pada Tabel 4.3 sebagai berikut :

\begin{tabular}{llrr}
\hline No & Persepsi Ibu & \multicolumn{2}{c}{ Responden } \\
\cline { 3 - 4 } & Hamil & Jumlah & Persentase \\
1. & Positif & 45 & 90,0 \\
2. & Negatif & 5 & 10,0 \\
& Jumlah & 50 & 100,0 \\
\hline
\end{tabular}

Tabel 4.3 menunjukkan bahwa responden persepsi positif memiliki proporsi tinggi (90,0\%) dibandingkan responden yang proporsi negative $(10,0 \%)$.

\section{b. Persepsi Kehamilan Pemeriksaan}

\section{Kehamilan Ke Tenaga Kesehatan}

Berdasarkan hasil wawancara yang dilakukan, distribusi frekuensi Persepsi Kehamilan Pemeriksaan kehamilan ke tenaga kesehatan dapat diketahui pada Tabel 4.4 sebagai berikut :

\begin{tabular}{|c|c|c|c|}
\hline \multirow[t]{2}{*}{ No } & \multirow[b]{2}{*}{$\begin{array}{l}\text { Kehamilan } \\
\text { Pemeriksaan } \\
\text { kehamilan } \\
\text { ke tenaga } \\
\text { kesehatan }\end{array}$} & \multicolumn{2}{|c|}{ Responden } \\
\hline & & Jumlah & Persentase \\
\hline 1. & Ya & 45 & 90,0 \\
\hline 2. & Tidak & 5 & 10,0 \\
\hline & Jumlah & 50 & 100,0 \\
\hline
\end{tabular}

Tabel 4.4 menunjukkan bahwa responden yang selama kehamilan melakukan pemeriksaan kehamilan ke tenaga 
kesehatan memiliki memiliki proporsi tinggi $(90,0 \%)$ dibandingkan responden yang tidak melakukan pemeriksaan kehamilan ke tenaga kesehatan $(10,0 \%)$.

\section{c. Kebiasaan Ibu Hamil Mengkonsumsi}

\section{Gizi Seimbang Setiap Hari}

Berdasarkan hasil wawancara yang dilakukan, distribusi frekuensi Kebiasaan ibu hamil mengkonsumsi gizi seimbang.

Tabel 4.5 Distribusi Frekuensi Kebiasaan ibu hamil mengkonsumsi gizi seimbang setiap hari :

\begin{tabular}{llcc}
\hline No & $\begin{array}{l}\text { Kebiasaan ibu } \\
\text { hamil } \\
\text { mengkonsumsi } \\
\text { gizi seimbang }\end{array}$ & \multicolumn{2}{c}{ Responden } \\
setiap hari & & \\
& & & \\
1. & Ya & 46 & 92,0 \\
2. & Tidak & 4 & 8,0 \\
& Jumlah & 50 & 100,0 \\
\hline
\end{tabular}

Tabel 4.5 menunjukkan bahwa responden yang memiliki kebiasaan Kebiasaan ibu hamil mengkonsumsi gizi seimbang setiap hari memiliki proporsi tinggi $(92,0 \%)$ dibandingkan responden yang tidak memiliki kebiasaan Kebiasaan ibu hamil mengkonsumsi gizi seimbang setiap hari $(8,0 \%)$.

\section{d. Kebiasaan Ibu Hamil Olah Raga}

Berdasarkan hasil wawancara yang dilakukan, distribusi frekuensi Kebiasaan ibu hamil olah raga.

Tabel 4.6 Kebiasaan ibu hamil olah raga

\begin{tabular}{llrr}
\hline No & $\begin{array}{c}\text { Kebiasaan } \\
\text { ibu hamil } \\
\text { olah raga }\end{array}$ & \multicolumn{2}{c}{ Responden } \\
\cline { 3 - 4 } & & & \\
& & 48 & \\
1. & Tidak & 2 & Pumlah \\
2. & Ya & 50 & 100,0 \\
\hline & Jumlah & & 4,0 \\
\hline
\end{tabular}

Tabel 4.6 menunjukkan bahwa responden yang tidak memiliki kebiasaan Kebiasaan ibu hamil olah raga memiliki proporsi tertinggi $(96,0 \%)$ dibandingkan responden yang memiliki Kebiasaan ibu hamil olah raga $(4,0 \%)$.

\section{E. PEMBAHASAN}

Penelitian ini menggunakan rancangan deskriptif dengan 50 sampel. Penelitian ini bertujuan untuk mengetahui gambaran persepsi dan kebiasaan masa hamil di Dusun Gunung Kawung Kecamatan Singaparna Kabupaten Tasikmalaya Tahun 2017. Analisis yang digunakan adalah analisis univariat. 
1. Karakteristik Responden

Pada penelitian ini karakteristik responden berdasarkan pekerjaan proporsi paling tinggi adalah IRT sebesar $62,0 \%$. Berdasarkan umur yang diduduki responden proporsi terbanyak adalah umur 21-25 sebesar $48,0 \%$. Umur yang terlalu muda pada saat hamil akan mempengaruhi persepsi dan kebiasaan selama masa kehamilan. Umur yang terlalu muda akan berisiko pada janin yang dikandungnya, selain itu juga dalam kebiasaan pemeriksaan hamil terkadang tidak secara bijak dalam menentukan fasilitas dalam pemeriksaan. Usia yang terlalu muda masih dalam pengaruh orang tua dalam kebiasaan pemeriksaan, kebiasaan hidup sehat dalam mengkonsumsi makanan gizi seimbang dan senam hamil. Usia muda juga banyak dipengaruhi orang tua yang berpersepsi mitos, sehingga akan mempengaruhi persepsi dan kebiasaan. Di Gunung Kawung sebagian besar profesi atau pekerjaanya adalah Ibu Rumah Tangga. Hal ini juga mempengaruhi terhadap pola fikir jika ibu rumah tangga yang tidak aktif dalam mencari sumber informasi kehamilan yang sehat. Sebaliknya meskipun ibu rumah tangga jika aktif dalam mencari sumber informasi dan pengetahuan akan mempengaruhi persepsi dan kebiasaan selama masa kehamilan.

2. Gambaran Persepsi dan Kebiasaan Ibu Hamil Selama Kehamilan di Gunung Kawung

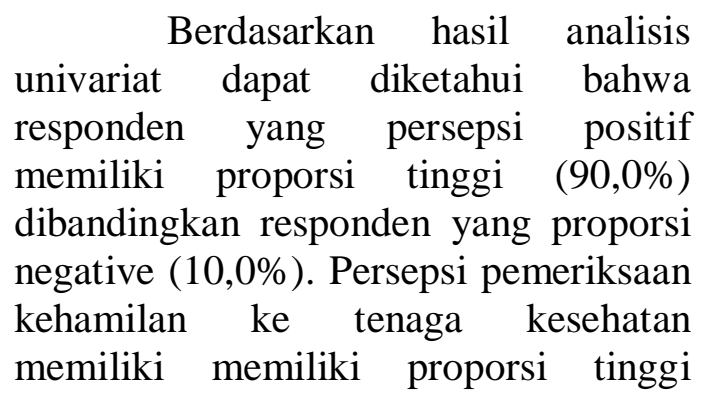

(90,0\%) dibandingkan responden yang tidak melakukan pemeriksaan kehamilan ke tenaga kesehatan $(10,0 \%)$. responden yang memiliki kebiasaan Kebiasaan ibu hamil mengkonsumsi gizi seimbang setiap hari memiliki proporsi tinggi $(92,0 \%)$ dibandingkan responden yang tidak memiliki kebiasaan Kebiasaan ibu hamil mengkonsumsi gizi seimbang setiap hari (10,0\%). Responden yang tidak memiliki kebiasaan Kebiasaan ibu hamil olah raga memiliki proporsi tertinggi (96,0\%) dibandingkan responden yang memiliki Kebiasaan ibu hamil olah raga $(4,0 \%)$. Persepsi ibu hamil di Gunung Kawung sudah bagus karena berpersepsi positif lebih banyak daripada yang negatif. Selain itu kesadaran untuk memeriksakan ke tenaga kesehatan sudah lebih banyak daripada yang tidak. Sedangkan kebiasaan mengkonsumsi gizi seimbang mulai tumbuh kesadaran dalam pemenuhan gizi selama hamil untuk mencegah anemia, kekuarangna zat besi dan kekurangan serat. Akan tetapi dalam kebiasaan olah raga masih rendah yaitu sebesar 5\% yang aktif melakukan senam hamil. Hal ini akan bermasalah jika ibu hamil kurang bergerak atau kurang olah raga. Hasil studi Higginbottom (2014) di Canada juga menemukan wanita hamil harus makan lebih sering dan atau dengan porsi yang lebih besar, banyak minum susu (dan juga jus apel) supaya kulit bayinya bagus dan juga untuk kesehatan dan kesejahteraan janin. Selain itu, penelitian yang dilakukan Otoo (2015) di Ghana menemukan buah-buahan, kepiting dan pisang mentah baik untuk ibu hamil karena buah-buahan dan kepiting membuat ibu dan janin sehat dan pisang mentah keras sehingga membuat janin kuat dan juga memberi 
kekuatan pada ibu saat persalinan. Studi Graft (2014) yang melakukan studi ke wanita dari 35 etnik yang ada di Ghana tentang keyakinan dan praktik makanan dalam kehamilan menyimpulkan bahwa makanan tradisional dan suplemen memiliki lima fungsi yaitu mencegah anemia, menguatkan tubuh ibu hamil, meningkatkan kesehatan, meminimalkan gangguan fisiologis dan memaksimalkan kesehatan bayi. Perilaku atau kebiasaan saat hamil juga harus dijaga sebagai bentuk perlindungan terhadap ibu dan janin. Keharusan menjaga perilaku dan menghindari pertengkaran ditekankan pada ibu hamil (Naidu:2013; M'soka et al: 2010). Wanita hamil juga hanya makan yang dimasak sendiri atau keluarganya, menggunakan artefak religi dan membawa kitab suci (Aziato et al:2016). Berdasarkan hasil penelitian juga telah terungkap adanya perbedaan persepsi dan kebiasaan masyarakat dalam merespon ketika anak sakit. Mereka yang mempunyai persepsi ketika anak panas disebabkan oleh adanya gangguan penyakit, maka akan mencari pengobatan melalui tenaga kesehatan. Namun jika masyarakat mempunyai persepsi ketika anak kejangkejang dianggap karena tasapo (guna-guna), akan mencari pengobatan non medis atau melalui dukun kampung. Hasil penelitian yang dilakukan Kresno, Sudarti dkk di Jakarta Utara juga mengungkapkan adanya persepsi masyarakat mengenai pengobatan bagi bayi yang mengalami sakit diare berbeda dengan konsep medis. Masyarakat beranggapan bahwa penyebab diare pada bayi adalah disebabkan karena bayi tersebut sedang mengalami proses peningkatan kepandaian, sehingga hal ini dianggap wajar dan tidak perlu diobati. Adanya perbedaan persepsi antara masyarakat dan petugas kesehatan inilah yang cenderung menimbulkan permasalahan dalam melaksanakan program kesehatan. Kondisi adanya perbedaan persepsi masyarakat antara masyarakat dan petugas kesehatan dalam merespon penyakit diare tersebut tentunya dianggap menjadi hambatan dalam upaya penurunan Angka Kematian Bayi (Notoatmodjo, 2010).

\section{F. KESIMPULAN DAN SARAN \\ 1. KESIMPULAN}

Berdasarkan hasil analisis dan pembahasan dapat disimpulkan sebagai berikut :

1.Gambaran karakteristik responden berdasarkan pekerjaan proporsi paling tinggi adalah IRT sebesar $62,0 \%$, berdasarkan umur yang proporsi terbanyak adalah umur 2125 sebesar $48,0 \%$.

2. Gambaran persepsi positif sebesar 90\%, Persepsi pemeriksaan kehamilan ke tenaga kesehatan memiliki memiliki proporsi tinggi $(90,0 \%)$ sedangkan responden yang tidak melakukan pemeriksaan kehamilan ke tenaga kesehatan $(10,0 \%)$.

3. Gambaran Kebiasaan ibu hamil mengkonsumsi gizi seimbang setiap hari $(92,0 \%)$. Responden yang tidak memiliki kebiasaan ibu hamil olah raga memiliki proporsi tertinggi $(96,0 \%)$.

\section{SARAN}

\section{Bagi Ibu Hamil}

a. Sebaiknya usia ketika hamil lebih diperhatikan demi keselamatan dan kesehatan 
ibu maupun janin yang dikandung

b. Ibu hamil sebaiknya memiliki persepsi yang baik dalam memeriksakan kehamilan dan selalu berpersepsi yang positif yang sesuai dengan norma agama dan kesehatan

c. Ibu hamil sebaiknya lebih banyak melakukan aktivitas fisik untuk seperti senam hamil dan aktivitas fisik lainnya yang ringan dan mudah dilakukan pada masa hamil.

\section{G. DAFTAR PUSTAKA}

Boediman D., 2009. Sehat Bersama

Gizi. Jakarta:Sagung Seto.

Dinas Kesehatan. (2017). Profil Data kesehatan Indonesia Tahun 2017. Jakarta: Kemenatrian Republik Indonesia

Prawita, A., Susanti, A. I. and Sari, P. (2018) 'Survei Intervensi Ibu Hamil Kurang Energi Kronik (Kek) Di Kecamatan Jatinangor Tahun 2015', Jurnal Sistem Kesehatan. doi: 10.24198/jsk.v2i4.12492.

Rukmana, S. C. and Kartasurya, M. I. (2014) 'Hubungan Asupan Gizi dan Status Gizi Ibu Hamil Trimester III dengan Berat Badan Lahir Bayi di Wilayah Kerja Puskesmas Suruh Kabupaten Semarang', Journal of Nutrition College.

Kementrian Kesehatan RI. 2014. Pedoman Gizi Seimbang. Direktorat Jenderal Bina Gizi dan KIA, Jakarta, hal. 24-26. 